\title{
Glutamate-stimulated Protein Phosphorylation in Cultured Hippocampal Pyramidal Neurons
}

\author{
W. K. Scholz and H. C. Palfrey \\ University of Chicago, Department of Pharmacological and Physiological Sciences, Chicago, Illinois 60637
}

\begin{abstract}
The regulation of second-messenger production and protein phosphorylation by glutamate has been investigated in primary cultures of pure hippocampal pyramidal neurons. Embryonic rat pyramidal neurons were prepared according to the procedures of Bartlett and Banker (1984) and studied 1-21 d after plating. Glutamate caused a transient increase in intracellular free $\left[\mathrm{Ca}^{2+}\right]$, determined with fura-2, in the presence of $1.26 \mathrm{~mm}$ extracellular $\mathrm{Ca}^{2+}$, but not in $50 \mathrm{~nm}$ free $\mathrm{Ca}^{2+}$-containing solution. Glutamate also transiently increased cellular diacylglycerol content in both normal and low-[ $\left.\mathrm{Ca}^{2+}\right]$ media. Neurons were prelabeled with ${ }^{32} \mathrm{P}$-orthophosphate to label intracellular ATP, then stimulated with glutamate $(100 \mu \mathrm{M})$. A rapid transient incorporation of ${ }^{32} \mathrm{P}$ into primarily three proteins of 120,87 , and $48 \mathrm{kDa}$ was found by analysis of two-dimensional gels. At $30 \mathrm{sec}$ after glutamate stimulation, ${ }^{32} \mathrm{P}$ incorporation into the $87-\mathrm{kDa}$ and 48 $k$ Da proteins peaked $(240 \%$ and $170 \%$ basal levels, respectively), and by $2 \mathrm{~min}$, phosphorylation of the $87-\mathrm{kDa}$ protein had returned to basal levels, while that of the 48kDa protein decreased but remained above control levels. The phosphorylation of these proteins appeared to be mediated by protein kinase C (PKC) because all three showed an increase in phosphorylation after phorbol ester treatment of cultures. Phosphate incorporation was accompanied by an acidic shift in the isoelectric point of both 87- and 48-kDa proteins. Glutamate stimulation resulted in phosphorylation in the presence and absence of $\mathrm{Ca}^{2+}$ influx. Antibody recognition and biochemical characteristics indicated that the 87-kDa phosphoprotein is the PKC substrate MARCKS (myristoylated, alanine-rich C-kinase substrate). The $48-\mathrm{kDa}$ protein, though very similar to GAP-43, was not recognized by specific antibodies raised against GAP-43. These results suggest that glutamate stimulates the transient generation of second messengers that activate PKC in hippocampal neurons, resulting in a significant increase in the phosphorylation of three specific proteins.
\end{abstract}

\footnotetext{
Received Nov. 20, 1990; revised Feb. 18, 1991; accepted Mar. 11, 1991.

We thank Drs. Katherine Albert and Angus Nairn for providing antibody to MARCKS, Betsy Apel and Dr. Daniel Storm for polyclonal rabbit antibody to neuromodulin, and Drs. David Schreyer and Pate Skene for monoclonal antibody to GAP-43. We also thank Dr. Kenneth Scholz for $\left[\mathrm{Ca}^{2+}\right]$ measurements. We are especially grateful to Drs. Jack Waymire and Jeffrey Johnston for assistance with reverse-phase HPLC analyses that were done by W.K.S. while in the laboratory of Dr. Paul Kelly and to Ankit Shah for technical assistance.

Correspondence should be addressed to W. K. Scholz, University of Chicago, Department of Pharmacological and Physiological Sciences, 947 East 58th Street, Chicago, IL 60637.

Copyright (c) 1991 Society for Neuroscience $0270-6474 / 91 / 112422-11 \$ 03.00 / 0$
}

In the hippocampus, mossy fibers of dentate granule cells and Schaffer collaterals and commissural fibers of other pyramidal neurons form synapses on pyramidal neurons. The excitatory neurotransmitter is probably glutamate (Watkins and Evans, 1981). Glutamate is believed to activate at least five distinct receptor subtypes (Monaghan et al., 1989) that can be functionally divided into two categories: those that directly gate ion channels ("ionotropic") and those that are directly associated with phospholipid turnover ("metabotropic"). Specific subtypes have been defined by the selective agonists of glutamate: NMDA, kainate, $\alpha$-amino-3-hydroxy-5-methylisoxazole-4-propionic acid (AMPA), trans-1-aminocyclopentane-1,3-dicarboxylic acid (trans-ACPD), and L-2-amino-4-phosphonobutyrate, as well as by several antagonists including 2-amino-5-phosphonovalerate (APV; NMDA receptor antagonist; Davies et al., 1981) and 6-cyano-7-nitroquinoxaline-2,3-dione (CNQX; selectively blocks kainate and AMPA receptor subtypes; Blake et al., 1988).

NMDA, kainate, and quisqualate receptors operate channels that can directly gate $\mathrm{Ca}^{2+}$ entry or mediate an $\mathrm{Na}^{+}$-dependent depolarization that opens voltage-dependent $\mathrm{Ca}^{2+}$ channels (Westbrook and Jahr, 1989). In addition, glutamate has been shown to stimulate the hydrolysis of phosphoinositides resulting in the liberation of inositol 1,4,5-triphosphate and diacylglycerol (DAG) in various CNS preparations (Sladeczek et al., 1985; Nicoletti et al., 1986; Recasens et al., 1987; for review, see Sladeczek et al., 1988). This phenomenon has largely been attributed to a metabotropic quisqualate-receptor subtype $\left(Q_{p}\right.$, or trans-ACPD). Inositol 1,4,5-trisphosphate binding to a receptor in the endoplasmic reticulum has been shown in a number of cell types to cause the release of stored $\mathrm{Ca}^{2+}$, thereby raising intracellular $\left[\mathrm{Ca}^{2+}\right]$ (Berridge, 1988; Ross et al., 1989), while DAG is an activator of protein kinase C (PKC; Nishizuka, 1986). A rise in both of these second messengers potentially leads to the activation of PKC as well as $\mathrm{Ca}^{2+} /$ calmodulin-dependent protein kinases. Though glutamate has been shown to activate PKC in certain types of nervous system preparations (e.g., Manzoni et al., 1990), studies of glutamate-stimulated protein phosphorylation have not shown increases in the phosphorylation of specific kinase substrates. However, an NMDA-stimulated decrease in microtubule-associated protein MAP2 phosphorylation was reported in hippocampal slices (Halpain and Greengard, 1990). A complication in working with slice preparations or mixed neuron-glia cultures is the existence of glutamate receptors in certain non-neuronal cell types (Pearce et al., 1986). Thus, to examine glutamate responses in neurons, it is preferable to study a homogeneous cultured cell system that is physiologically stimulated by this neurotransmitter and is amenable to biochemical analysis. Consequently, we have examined gluta- 
mate-stimulated processes in pure cultures of hippocampal pyramidal neurons.

Several phosphoproteins that are considered to be important in signal transduction in the nervous system have been described (for reviews, see Palfrey and Mobley, 1987; Hemmings et al., 1989). In particular, two substrates for PKC, myristoylated, alanine-rich, C-kinase substrate (MARCKS; Stumpo et al., 1989; also known as " $87 \mathrm{~K}$ "; Wu et al., 1982) and growth-associated protein-43 (GAP-43; very similar or identical to B-50, neuromodulin, F1, P-57, pp46; Zwiers et al., 1980; Skene and Willard, 1981a,b; Andreason et al., 1983; Cimler et al., 1985; Katz et al., 1985; Nelson and Routtenberg, 1985), have been implicated in a variety of neuronal processes. MARCKS is found in a number of tissues (Albert ct al., 1986), while GAP-43 is neural specific (Cimler et al., 1985). In this study, we show that glutamate activates a PKC-dependent phosphorylation of MARCKS and two other proteins, but has little effect on GAP-43.

\section{Materials and Methods}

Pyramidal neuron cultures. Astrocytes were prepared by the procedure of Booher and Sensenbrenner (1972). After $4 \mathrm{~d}$ in culture, astrocytes were removed from the plates with trypsin and replated on $30-\mathrm{mm}$ Thermanox coverslips equipped with Paraplast "feet." Pyramidal neuron cultures were prepared from the hippocampi of fetal rats of $17 \mathrm{~d}$ gestation as described by Bartlett and Banker (1984) with some modifications. Hippocampi were dissected in $\mathrm{Ca}^{2+}$ and $\mathrm{Mg}^{2+}$-free Hanks' balanced salt solution (HBSS) and incubated in $0.25 \%$ trypsin (Gibco) for $20 \mathrm{~min}$. Tissue was dissociated by triturating one to seven passes with a normal-bore Pasteur pipette and seven to ten times with a flamenarrowed Pasteur pipette and plated in Dulbecco's modified Eagle's medium (Hazleton) plus 10\% horse serum (Gibco) on poly-L-lysine (Sigma; $0.5 \mathrm{mg} / \mathrm{ml}$ in borate buffer, $\mathrm{pH} 8.0$, as described by Banker and Cowan, 1977) coated $35-\mathrm{mm}$ tissue culture plates. After $2-4 \mathrm{hr}$ the medium was replaced with a serum-free defined medium (N2; Bottenstein and Sato, 1979, as modified by Bartlett and Banker, 1984), and coverslips of astrocytes were placed in each plate. Cytosine- $\beta$-D-arabinofuranoside $(5 \mu \mathrm{M})$ was added to each plate $3 \mathrm{~d}$ later to inhibit nonneuronal cell proliferation. The physical separation of the astrocyte monolayer from the neuronal monolayer enabled removal of the astrocytes immediately prior to performing experiments. For immunocytochemistry and experiments on intracellular $\mathrm{Ca}^{2+}$ levels, neurons were plated on $25-\mathrm{mm}$ round glass coverslips. Neurons were allowed to adhere for $2-4 \mathrm{hr}$ and then were transferred to $60-\mathrm{mm}$ dishes containing astrocytes attached to the bottom of the dish in N2 medium.

The hippocampal pyramidal cell layer was virtually homogeneous. Staining with anti-glial fibrillary acidic protein showed less than $5 \%$ astrocyte contamination. GABA staining with specific antibody showed that only about $5-10 \%$ of the neuronal population contained GABA, probably corresponding to hippocampal interneurons.

Measurement of $D A G$. DAG levels were determined by enzymatically converting extracted DAG to phosphatidic acid (Preiss et al., 1986, as modified by Wright et al., 1988). Pyramidal cultures were washed and incubated at $30^{\circ} \mathrm{C}$ with HEPES ( $20 \mathrm{~mm}$; pH 7.4)-buffered HBSS containing $1.26 \mathrm{mM} \mathrm{Ca}^{2+}$ for 15 min with gentle shaking. All buffers were $\mathrm{Mg}^{2+}$ free and contained $1 \mu \mathrm{M}$ glycine to allow activation of the NMDA receptor. For experiments using $50 \mathrm{nM} \mathrm{Ca}^{2+}$, a modified salt solution containing $10 \mathrm{~mm}$ HEPES (pH 7.4), $135 \mathrm{~mm} \mathrm{NaCl}, 5 \mathrm{~mm} \mathrm{KCl}, 5 \mathrm{~mm}$ EGTA, $1.9 \mathrm{~mm} \mathrm{CaCl}$, and $10 \mathrm{~mm}$ glucose was used. After glutamate (100 $\mu \mathrm{M}$ final) addition, medium was quickly aspirated and replaced with $1 \mathrm{ml} \mathrm{100 \%} \mathrm{methanol} \mathrm{at} \mathrm{the} \mathrm{times} \mathrm{indicated;} 1 \mathrm{ml}$ chloroform and $1.8 \mathrm{ml}$ of $1 \mathrm{M} \mathrm{NaCl}$ were then added. Following phase separation, the chloroform extract was dried under nitrogen and incubated with a purified DAG kinase (Lipidex; $4 \mu \mathrm{g} / 100 \mu \mathrm{l}$ ) and $\gamma^{-32} \mathrm{P}$-ATP (Amersham; $2 \mu \mathrm{Ci} / 100 \mu \mathrm{l}$ ), for $30 \mathrm{~min}$ at room temperature. The ${ }^{32} \mathrm{P}$-phosphatidic acid produced was separated by thin-layer chromatography, detected by autoradiography, scraped from plates, and quantified by scintillation counting.

Measurement of intracellular $\left[\mathrm{Ca}^{2+}\right]$. Intracellular $\mathrm{Ca}^{2+}$ levels were measured using the fluorescent indicator dye fura- 2 as described by Thayer et al. (1988). Cultured pyramidal neurons were loaded with fura-2 acetoxymethyl ester (Molecular Probes; $4 \mu \mathrm{M}$ ) in HEPES-buffered
HBSS for $\mathbf{4 5} \mathrm{min}$ and postincubated for $30 \mathrm{~min}$ with HEPES-buffered HBSS to allow hydrolysis of the ester. Neurons were stimulated by switching the inlet reservoir of the perfusion chamber from HEPESbuffered HBSS to $60 \mu \mathrm{M}$ glutamate in buffer containing either $50 \mathrm{nM}$ or $1.26 \mathrm{mM} \mathrm{Ca}^{2+}$. Approximate intracellular free $\left[\mathrm{Ca}^{2+}\right]$ was calculated from the ratio of fluorescence obtained from excitation of 340 and 380 $\mathrm{nm}$ using the method of Grynkiewicz et al. (1985).

Determination of $\gamma_{-}{ }^{32} P-A T P$ specific activity. The specific activity and time course of ${ }^{32} \mathrm{P}$-orthophosphate $\left({ }^{32} \mathrm{P}_{\mathrm{i}}\right)$ incorporation into ATP and $\gamma$-32 P-ATP was determined as described by Waymire et al. (1988). Briefly, neurons were incubated with ${ }^{32} \mathbf{P}_{\mathrm{i}}$, washed with HEPES-buffered HBSS, harvested with a rubber policeman, collected by centrifugation $(100 \times$ $g$ for $5 \mathrm{~min}$ ), extracted with $0.4 \mathrm{M}$ perchloric acid, and neutralized. Extracts were analyzed by reverse-phase HPLC using a Waters C-18 $\mu$ Bondapak column and a $0-37 \%$ acetonitrile gradient in $60 \mathrm{~mm} \mathrm{KH}_{2} \mathrm{PO}_{4}$ and $4 \mathrm{~mm}$ tetrabutyl ammonium hydrogen sulfate. ATP peaks were quantitated by ultraviolet absorption at $259 \mathrm{~nm}$ and ${ }^{32} P$ incorporation quantified by Cerenkov counting. The pooled ${ }^{32} \mathrm{P}$-ATP fractions were further analyzed for $\gamma^{-32}$ P-ATP specific activity by incubation with hexokinase and quantitation of the radioactivity in glucose-6-phosphate, ADP, and ATP using reverse-phase HPLC and Cerenkov counting. The time course of phosphate incorporation into neuronal proteins obtained from cultures incubated in ${ }^{32} \mathrm{P}_{\mathrm{i}}$ for 5-90 min was analyzed by SDS-PAGE. ${ }^{32} \mathrm{P}$ incorporation into individual proteins was assessed by excising specific phosphoproteins $(87,58,54$, and $20 \mathrm{kDa})$ and liquid scintillation counting.

Glutamate-stimulated protein phosphorylation. Two $35-\mathrm{mm}$ plates, each containing approximately $3 \times 10^{5}$ cells in the neuronal plane $(\approx 8$ $\mu \mathrm{g}$ protein) were used per sample. All plates used for a single experiment contained identical cell concentrations from the same dissociation. Coverslips containing astrocytes were removed, and the neuronal layer was washed and equilibrated in low-phosphate HEPES-buffered HBSS $(5.6$ mм KCl, $0.2 \mathrm{~mm} \mathrm{KH} \mathrm{PO}_{4}, 137.6 \mathrm{~mm} \mathrm{NaCl}, 2.4 \mathrm{~mm} \mathrm{NaHCO}, 5.6 \mathrm{~mm}$ glucose, $0.4 \mathrm{mM} \mathrm{MgSO}_{4}, 0.5 \mathrm{~mm} \mathrm{MgCl}_{2}, 20 \mathrm{~mm}$ HEPES, pH 7.4) containing $50 \mathrm{nM}$ or $1.26 \mathrm{mM} \mathrm{Ca}^{2+}$ at $30^{\circ} \mathrm{C}$ in a gently shaking water bath. ${ }^{32} \mathbf{P}_{\mathbf{i}}$ (ICN Radiochemicals) was added to a final specific activity of 750 $\mu \mathrm{Ci} / \mathrm{ml}$, and incubation continued for $50 \mathrm{~min}$. Glutamate was then added from a stock solution to yield a final concentration of $100 \mu \mathrm{M}$. Each plate was removed from the shaker, the medium was quickly aspirated, and the cells were solubilized with $60 \mu$ l of SDS sample buffer maintained at $70^{\circ} \mathrm{C}$, at the times indicated. Labeled proteins were separated by slight modifications of the two-dimensional isoelectric focusing/SDS-PAGE method described by O'Farrell (1975). Proteins were resolved in the isoelectric focusing dimension using $2.7 \%(\mathrm{v} / \mathrm{v}) \mathrm{am}-$ pholyte mixture of $\mathrm{pH} 3.5-9.5(2.1 \%)$ and $\mathrm{pH} 2.5-4(0.6 \%$; PharmaciaLKB). Isoelectric focusing gels were then subjected to SDS-7.5\% PAGE. Gels were fixed, dried, and autoradiographed for $1-3 \mathrm{~d}$. Changes in phosphorylation resulting from 12-O-tetradecanoylphorbol 13-acetate (TPA; $100 \mathrm{nM}$ for $10 \mathrm{~min})$ and elevated $\left[\mathrm{K}^{+}\right](50 \mathrm{~mm}$ for $5-120 \mathrm{sec})$ treatments were also examined.

Two-dimensional tryptic and thermolytic fingerprints. Phosphoproteins corresponding to each isoelectric variant of the $87-\mathrm{kDa}$ or $48-\mathrm{kDa}$ species were excised from two-dimensional gels and individually fingerprinted (Palfrey and Mobley, 1987). Gel pieces were rehydrated and digested with $50 \mu \mathrm{g} / \mathrm{ml} \mathrm{L}$-1-tosyl-amido-2-phenylethyl chloromethyl ketone-treated trypsin (Sigma) or thermolysin (Calbiochem) in $50 \mathrm{~mm}$ ammonium bicarbonate ( $\mathrm{pH} \mathrm{8.3)} \mathrm{for} 24 \mathrm{hr}$. Phosphopeptides were separated by thin-layer electrophoresis at $\mathrm{pH} 3.5$ in the first dimension and chromatography in the second on $20 \times 20 \mathrm{~cm}$ cellulose plates (Palfrey and Mobley, 1987). Plates were dried, and individual phosphopeptides were revealed by autoradiography. Spots corresponding to individual phosphopeptides were scraped and quantified by scintillation counting.

Immunoblot analysis. Pyramidal neuron proteins were extracted with SDS sample buffer as described above and then separated by SDS- $7.5 \%$ PAGE and electrophoretically transferred to nitrocellulose (Towbin et al., 1979). Nitrocellulose sheets were incubated with rabbit polyclonal antibodies specific for MARCKS or GAP-43 diluted 1:200, or monoclonal antibody to GAP-43 (9-1E12) diluted 1:5000, in Tris-buffered saline with $1 \%$ BSA. All primary incubations were $90 \mathrm{~min}$ at room temperature. Antibody reactivity was visualized using a biotinylated anti-rabbit or anti-mouse antibody, followed by an avidin-biotinylated horseradish peroxidase complex (reagents from Vector Laboratories) with diaminobenzidine tetrahydrochloride and $\mathrm{H}_{2} \mathrm{O}_{2}$ as substrates.

For experiments in which immunoreactivity was colocalized with the ${ }^{32} \mathbf{P}$-labeled protein, pyramidal cultures were first labeled with ${ }^{32} \mathbf{P}_{\mathrm{i}}$. Pro- 
A

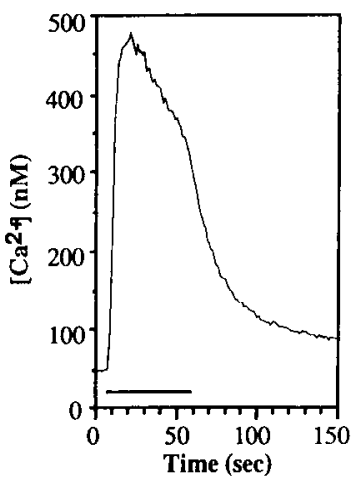

B

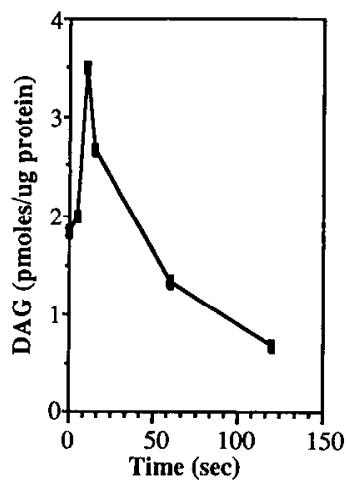

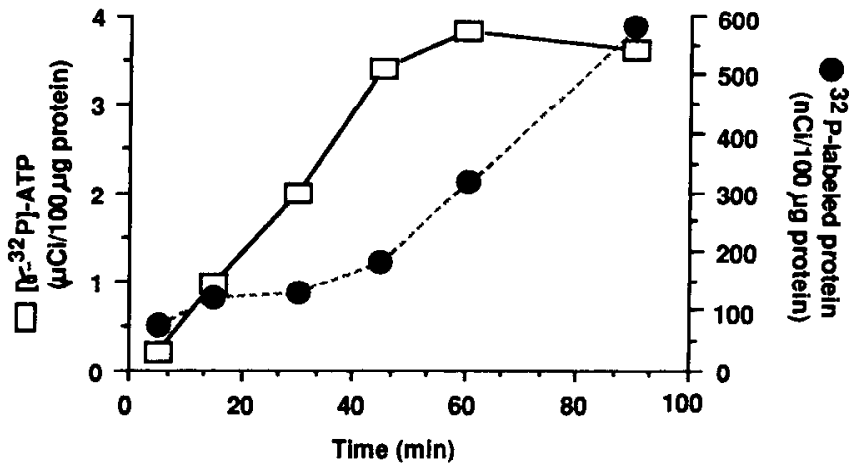

Figure 2. Time course of ${ }^{32} \mathrm{P}$ incorporation into the $\gamma$-position of ATP and protein following incubation of cultured pyramidal neurons with ${ }^{32} \mathbf{P}_{\mathrm{i}}$. Cultured pyramidal neurons were incubated with $750 \mu \mathrm{Ci} / \mathrm{ml}{ }^{32} \mathbf{P}_{\mathrm{i}}$ for 5-90 min. Neurons were harvested, and half of the cell pellet was extracted for reverse-phase IIPLC analyses of $\gamma^{-32} \mathrm{P}$-ATP (squares), while the remainder was analyzed by separating phosphoproteins by SDSPAGE and counting specific bands (circles). Results represent the average of two experiments.

found to be transient, peaking by 10 sec and returning to basal levels by $2 \mathrm{~min}$. Thus, glutamate stimulation results in the production of the appropriate second messengers that can potentially activate protein kinases, including PKC.

\section{Specific activity of intracellular ATP}

In order to optimize conditions for in situ protein phosphorylation experiments in pyramidal neurons, the specific activity of ATP and protein phosphate was estimated after the addition of ${ }^{32} \mathrm{P}_{\mathrm{i}}$ to the medium. Pyramidal neurons at $14-21 \mathrm{~d}$ in culture were labeled, and the specific activities of total ${ }^{32} \mathrm{P}$-ATP and $\gamma_{-}{ }^{32} \mathrm{P}-\mathrm{ATP}$ were determined as described in Materials and Methods. Pyramidal neurons contained approximately $1.3 \mathrm{nmol}$ of ATP per $100 \mu \mathrm{g}$ of neuronal protein. The specific activity of $\gamma-{ }^{32}$ P-ATP increased over a $45-\mathrm{min}$ labeling period then plateaued at about $3 \mu \mathrm{Ci} / \mathrm{nmol}$, which represented approximately $30 \%$ of the total labeled ATP (Fig. 2, squares). On the other hand, analysis of neuronal phosphoproteins indicated that ${ }^{32} \mathrm{P}$ incorporation did not initially parallel the rise in ATP specific activity, but exhibited a lag until 40-60 min and continued to rise through $90 \mathrm{~min}$ of incubation (Fig. 2, circles). Although phosphorylation/dephosphorylation may not have reached an equilibrium, ${ }^{32} \mathrm{P}$ turnover of all proteins examined by two-dimensional gel electrophoresis in the present experiments showed the same relative incorporation whether incubation with ${ }^{32} \mathrm{P}_{1}$ was carried out for 5 to 60 min. We chose a $45-55-\mathrm{min}^{32} \mathrm{P}_{\mathrm{i}}$ incubation, because at this time ${ }^{32} \mathrm{P}$ labeling of ATP pools was at equilibrium, yet protein phosphorylation was low, thus maximizing the ratio of stimulated to basal phosphorylation.

\section{Glutamate-stimulated phosphorylation of three specific proteins}

Addition of glutamate ( $100 \mu \mathrm{M}$ final) to prelabeled cultures rapidly stimulated protein phosphorylation. The effect was most markcd in three proteins of 120,87 , and $48 \mathrm{kDa}$ and isoelectric points between 4 and 5 (Fig. $3 a, b$ ). Increases in the phosphorylation of the $\alpha$ - and $\beta$ - (50- and 60-kDa, respectively) subunits of $\mathrm{Ca}^{2+} /$ calmodulin-dependent protein kinase II were not detected because of their relatively low level of ${ }^{32} \mathrm{P}$ incorporation. The increase in glutamate-stimulated phosphorylation was receptor mediated because it could be completely blocked by a an initial response. Generation of both second messengers was 


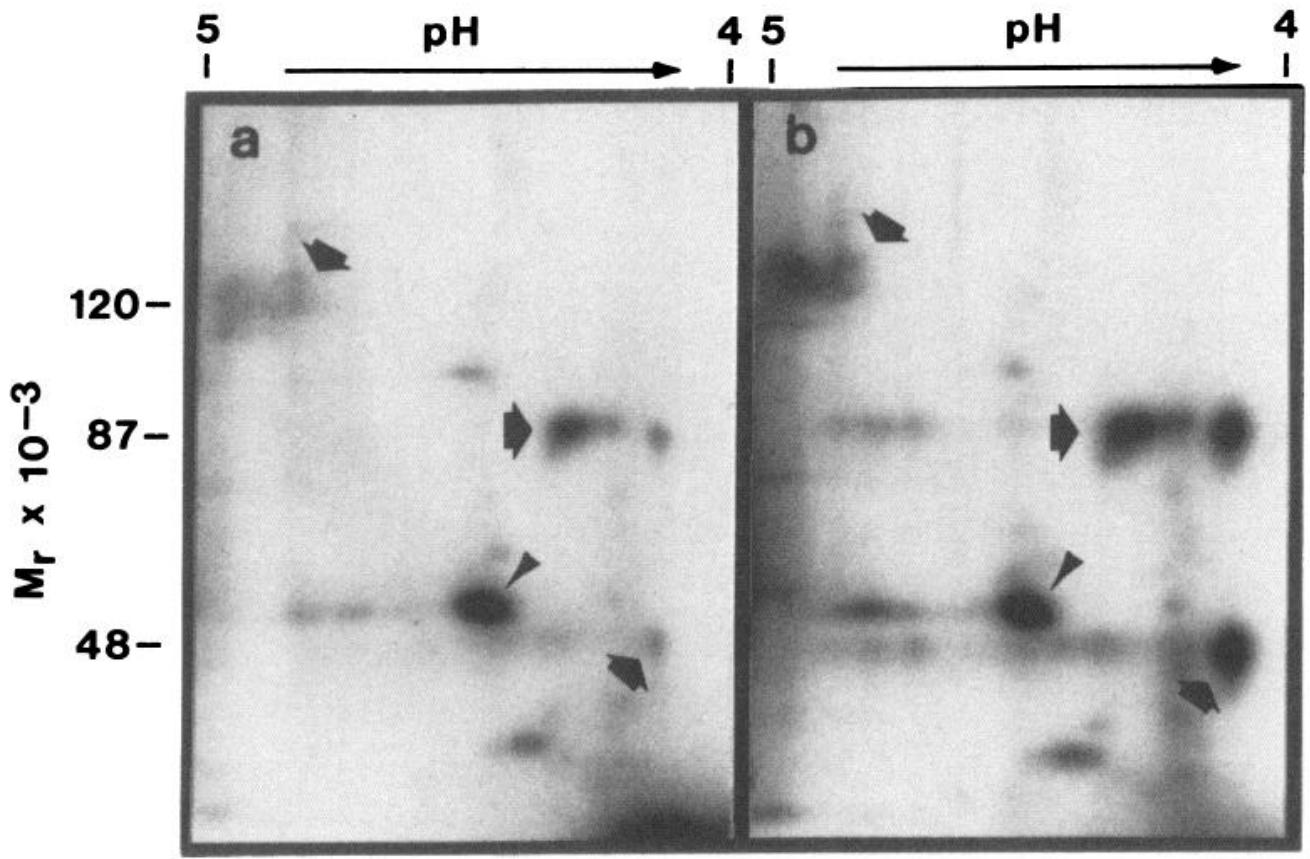

Figure 3. Glutamate-stimulated phosphorylation in cultured pyramidal neurons. Pyramidal neurons in culture for $14 \mathrm{~d}$ were incubated with ${ }^{32} \mathrm{P}_{\mathrm{i}}$ for 50 $\mathrm{min}$ and then either treated for $1 \mathrm{~min}$ with $100 \mu \mathrm{M}$ glutamate $(b)$ or left untreated $(a)$. Proteins were separated by two-dimensional IEF/SDS-PAGE and autoradiographed. The $\mathrm{pH}$ range shown extends from $\mathrm{pH} 5$ (at left of chromatogram) to $\mathrm{pH} 4$. Arrows indicate the 120-, 87-, and 48-kDa proteins, and the arrowheads indicate a major phosphoprotein, GAP-43, that shows little change in phosphorylation level.

combination of CNQX (500 $\mu \mathrm{M})$ and APV (500 $\mu \mathrm{M})$. The phosphorylation of $87-$ and $48-\mathrm{kDa}$ phosphoproteins remained at basal levels when these antagonists were added $5 \mathrm{~min}$ before glutamate (see Fig. 5C). Confirmation that the 120-, 87-, and 48-kDa proteins were substrates for PKC was obtained in experiments where cultures were stimulated with TPA (100 nM). All three proteins exhibited an increase in phosphorylation under these conditions, but phorbol esters did not mimic the highly selective effect of glutamate in that an increase in the phosphorylation of many other proteins was observed (Fig. $4 a, b$ ).

The increased phosphorylation of the $87-$ and $48-\mathrm{kDa}$ proteins following glutamate addition was transient (Fig. 5). Highest incorporation of ${ }^{32} \mathrm{P}$ occurred at $30 \mathrm{sec}$ and returned to near basal levels by $2 \mathrm{~min}$, even in the continued presence of glu- tamate. It should be noted that the $120-\mathrm{kDa}$ phosphoprotein was expressed in pyramidal neurons after about $10 \mathrm{~d}$ in culture and therefore is not seen in Figure 5. In neurons cultured for more than $10 \mathrm{~d}$, a similar time course of phosphorylation was observed for the isoelectric variants of 87- and 48-kDa proteins (data not shown). The 120-kDa protein also showed a transient phosphorylation, without a change in isoelectric point, that peaked at about $30 \mathrm{sec}$.

\section{Glutamate-stimulated DAG production and protein phosphorylation at low extracellular $\left[\mathrm{Ca}^{2+}\right]$}

To determine if glutamate-stimulated phosphorylation was due solely to depolarization-mediated $\mathrm{Ca}^{2+}$ influx through voltagedependent $\mathrm{Ca}^{2+}$ channels and/or receptor-operated $\mathrm{Ca}^{2+}$ entry

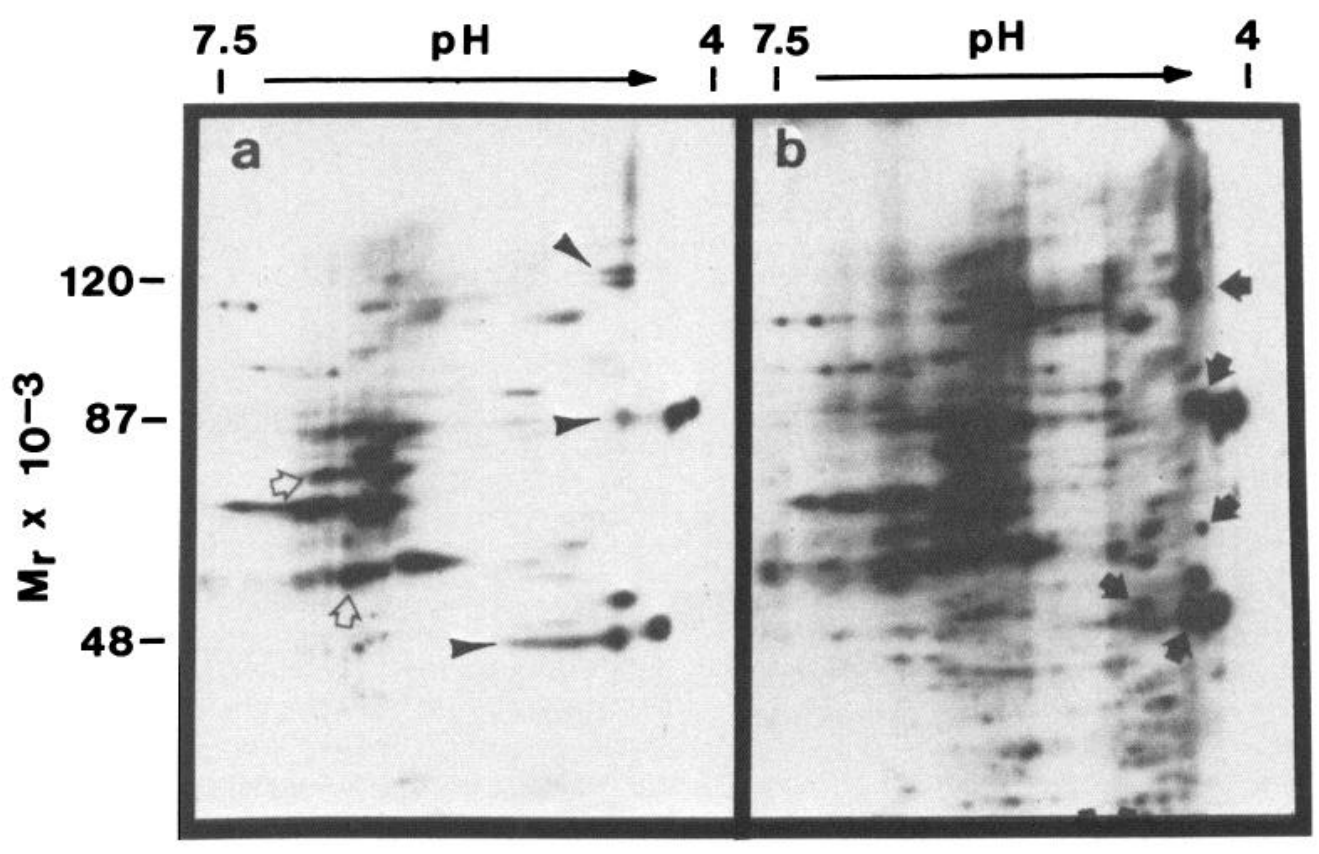

Figure 4. TPA-stimulated phosphorylation in pyramidal neurons. $a$ and $b$ show control and TPA (10 min)-stimulated phosphorylation observed in pyramidal neurons cultured for $14 \mathrm{~d}$. The $\mathrm{pH}$ gradient is somewhat compressed. showing a range of $\mathrm{pH} 7.5$ to $\mathrm{pH} 4$. Open arrows indicate phosphoproteins that show less ${ }^{32} \mathrm{P}$ incorporation or $\mathrm{mi}$ grate differently following treatment, and arrowheads show the 120-, 87-, and 48-kDa proteins. Solid arrows indicate clearly resolved proteins that show significant increases in phosphorylation following TPA treatment. 
A

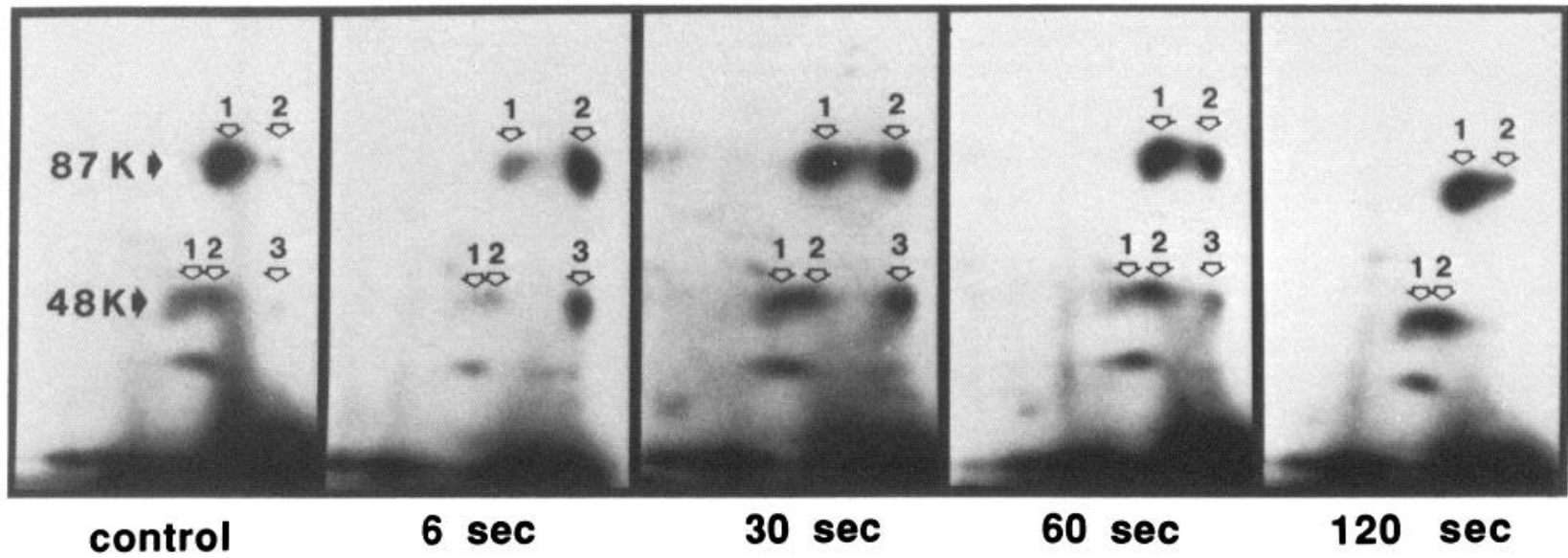

B
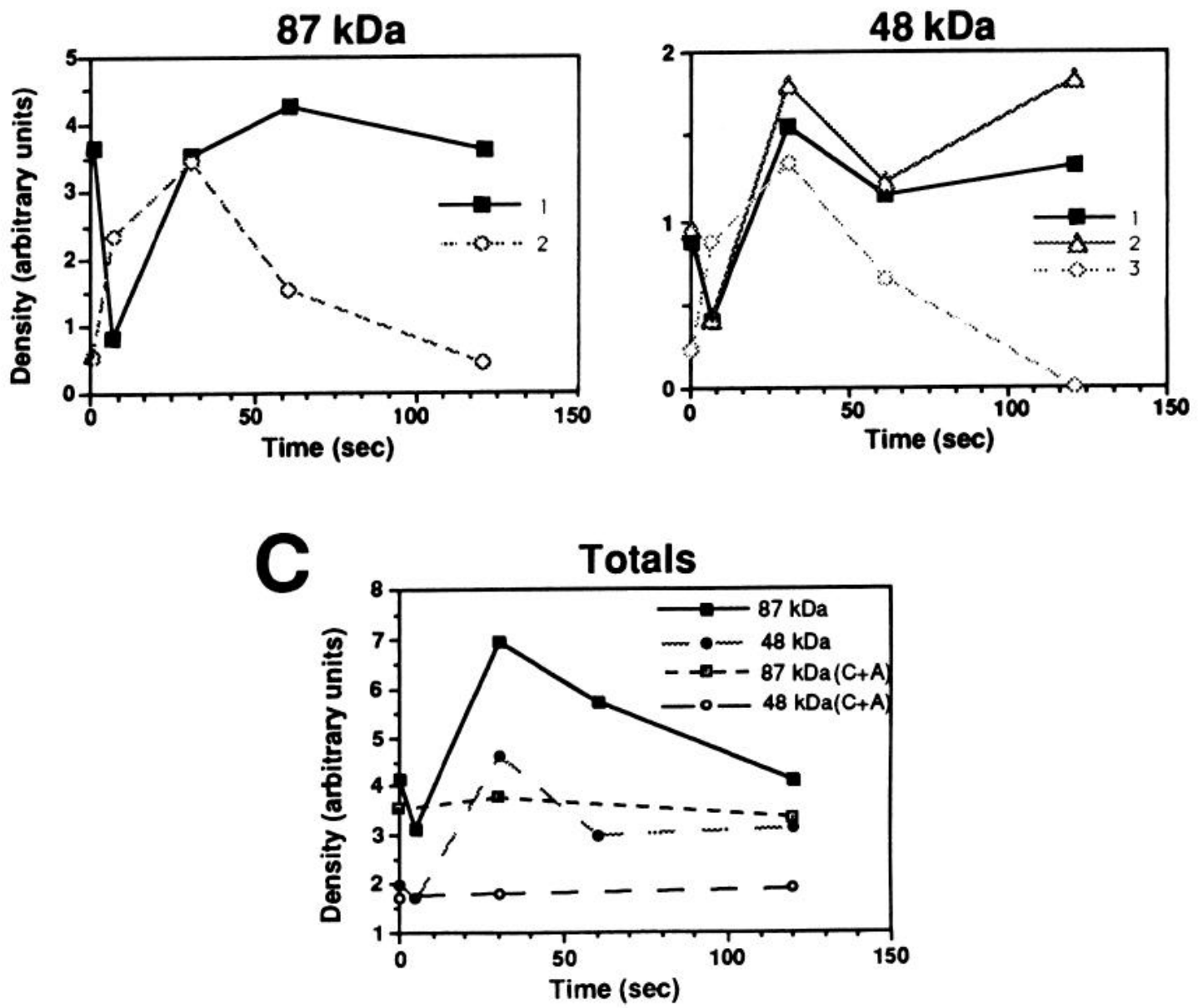

Figure 5. Time course of glutamate-stimulated protein phosphorylation. $A$ shows autoradiograms of two-dimensional gels of pyramidal neurons ( $4 \mathrm{~d}$ in culture) preincubated as described in Materials and Methods, then stimulated with glutamate $(100 \mu \mathrm{M})$ for different times. The different isoelectric variants of the $87-\mathrm{kDa}$ and $48-\mathrm{kDa}$ phosphoproteins are indicated by arrows $1-3$. These results are representative of five independent experiments on neurons cultured for 4-14 d. $B$ shows densitometric scans of the autoradiograms shown in $A$ to quantitate the relative amounts of the isoelectric variants of the $87-\mathrm{kDa}$ and $48-\mathrm{kDa}$ proteins. Changes in the total amount of radioactive protein (sum of isoelectric forms) and blocking effects of CNQX $(500 \mu \mathrm{M})$ and APV $(500 \mu \mathrm{M})$ on glutamate $(100 \mu \mathrm{M})$-stimulated phosphorylation of 87 - (squares) and 48- (circles) kDa proteins are shown in $C$.

pathways, phosphorylation was examined in an extracellular solution containing $50 \mathrm{nM}$ free $\mathrm{Ca}^{2+}$. Under these conditions, in which extracellular and intracellular $\left[\mathrm{Ca}^{2+}\right]$ are approximately equal, glutamate did not stimulate a change in intracellular free $\left[\mathrm{Ca}^{2+}\right]$ as determined by fura- 2 measurements (Fig. $6 \mathrm{~A}$ ). How- ever, glutamate was still capable of stimulating a transient rise in DAG (Fig. $6 B$ ) and an increase in phosphorylation of the 120-, 87-, and 48-kDa proteins (Fig. 6C). We have found that the responses in low $\mathrm{Ca}^{2+}$ tended to be smaller than those in normal $\mathrm{Ca}^{2+}$ and are currently evaluating the contribution of 

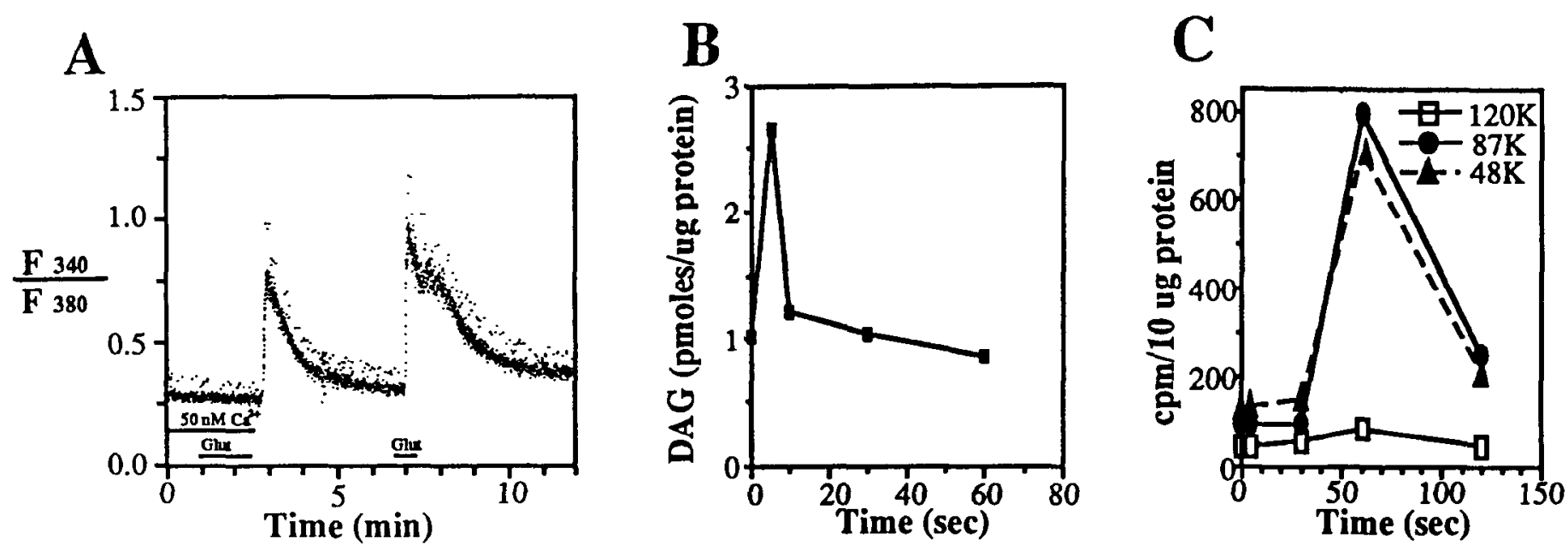

Figure 6. Glutamate-stimulated changes in second messengers and phosphorylation levels in $50 \mathrm{~nm}$ free $\mathrm{Ca}^{2+}-$ containing solution. A, Intracellular $\left[\mathrm{Ca}^{2+}\right]$ remained at basal levels in neurons stimulated with glutamate. As the low-Ca ${ }^{2+}$ buffer was replaced with one containing $1.26 \mathrm{~mm} \mathrm{Ca}{ }^{2+}$, a small $\mathrm{Ca}^{2+}$ transient was elicited due to residual glutamate in the bath. Finally, the same neuron was stimulated with glutamate a second time in normal extracellular $\left[\mathrm{Ca}^{2+}\right]$, which caused a large increase in intracellular $\left[\mathrm{Ca}^{2+}\right] . B, \mathrm{DAG}$ levels were determined in cultures stimulated by glutamate in the presence of $50 \mathrm{nM}$ free $\mathrm{Ca}^{2+}$. Neurons were stimulated with $100 \mu \mathrm{M}$ glutamate for times indicated, and DAG mass levels were determined as described in Figure 1 and Materials and Methods. This is representative of two independent experiments on pyramidal neurons in culture for $8 \mathrm{~d}$. $C$ shows stimulation of phosphorylation of the $120-\mathrm{kDa}, 87-\mathrm{kDa}$, and $48-\mathrm{kDa}$ proteins by glutamate in a medium containing $50 \mathrm{nM}$ free $\mathrm{Ca}^{2+}$. Cultures were preincubated with ${ }^{32} \mathrm{P}_{\mathrm{i}}$ in $50 \mathrm{nM} \mathrm{Ca}^{2+}$-containing solution prior to the addition of glutamate. Reactions were stopped at the times indicated, and the proteins were solubilized and separated on two-dimensional gels. The total radioactivity in the three phosphoproteins was determined by scintillation counting of gel pieces.

extracellular $\mathrm{Ca}^{2+}$ to the effects of glutamate. Nevertheless, these results suggest that $D A G$ production in response to glutamate is not merely a secondary consequence of $\mathrm{Ca}^{2+}$ entry and that DAG elevation alone is sufficient to stimulate PKC.

The possible role of depolarization in glutamate receptoractivated events was further investigated by comparing protein phosphorylation in the presence of glutamate with that induced by elevated $\left[\mathrm{K}^{+}\right]$. Depolarization with $50 \mathrm{~mm} \mathrm{~K}^{+}$, which also causes an increase in intracellular $\mathrm{Ca}^{2+}$ in these cells (Glaum et al., 1990; Scholz and Miller, 1991), led to a general increase in phosphate incorporation into many proteins analyzed by twodimensional gel electrophoresis (data not shown). This contrasts with the more selective effects of glutamate and suggests that glutamate-induced phosphorylation of the 120-, 87-, and 48kDa proteins cannot solely be due to the stimulation of $\mathrm{Ca}^{2+}$ influx through voltage-dependent $\mathrm{Ca}^{2+}$ channels.

Multiple phosphorylation sites in isoelectric variants of the 87$k D a$ and 48-kDa proteins

The 87-kDa and 48-kDa phosphoproteins could be separated into multiple isoelectric variants using the two-dimensional gel electrophoresis conditions described (Fig. 5). Glutamate stimulation caused a rapid (apparent by $5 \mathrm{sec}$ ) acidic shift in the isoelectric point of the major phosphorylated form of the 87 $\mathrm{kDa}$ protein, which reversed to the less acidic form by $2 \mathrm{~min}$. The 48-kDa phosphoprotein showed a similar shift in isoelectric point of the two major phosphorylated forms to a third, more acidic form.

The most likely explanation for the glutamate-activated isoelectric shift in both 87- and 48-kDa proteins is the addition of phosphate groups. To verify this, phosphopeptide analyses of each isoelectric variant were performed (Fig. 7). The 48-kDa protein appeared to consist of three isoelectric variants (Fig. $5 A$ ), each of which contained multiple thermolytic phosphopeptides (Fig. $7 D$ ). In the least acidic isoelectric variant of 48
$\mathrm{kDa}$ (Fig. $7 D, 48-1$ ), a peptide designated \#2 was the major species phosphorylated; in the next, more acidic variant (48-2), a phosphorylated peptide designated \#3 was also apparent; and the most acidic isoelectric variant (48-3) had these two peptides as well as two other phosphorylated peptides designated \#4 and \#6. Other peptides did not show significant changes after glutamate stimulation. Thus, the glutamate-stimulated shift in isoelectric point of the $48-\mathrm{kDa}$ protein may be explained by changes in the total number of phosphorylation sites on the protein. This does not appear to be the case for the $87-\mathrm{kDa}$ protein. Peptide fingerprints of the two isoelectric variants (designated 87-1 and 87-2) of this phosphoprotein showed little difference in intensity or migration. This was true of both tryptic (Fig. $7 A$ ) and thermolytic (Fig. $7 B$ ) digests. We consider explanations for this phenomenon in the Discussion.

\section{Identity of the 87- and 48-kDa phosphoproteins}

We next sought to analyze whether any of the three species exhibiting glutamate-stimulated phosphorylation were identical to previously described neuronal proteins. The $87-\mathrm{kDa}$ protein displayed a number of characteristics in common with MARCKS, including acidic isoelectric point, apparent molecular size of 87 $\mathrm{kDa}$, and multiple isoelectric variants (see Discussion). AntiMARCKS antibody recognized a single protein in both oneand two-dimensional gels of pyramidal cell total protein (Fig. $8 a, c)$. Immunoprecipitation of MARCKS with a specific polyclonal antibody showed that the phosphorylation of this protein increased approximately $50 \%$ following glutamate addition (Fig. $8 b$. lanes 1, 2). Phosphopeptide maps of immunoprecipitated MARCKS were identical to those of the $87-\mathrm{kDa}$ protein excised from two-dimensional gels (Fig. 7; cf. $B, C$ ). Colocalization, on the same nitrocellulose sheet, of immunolabeled MARCKS and ${ }^{32} \mathrm{P}$-labeled $87-\mathrm{kDa}$ protein after two-dimensional gel separation revealed an exact coincidence (Fig. $8 \mathrm{C}$ ). Using the same antibody, MARCKS was localized immunocytochemically in py- 
A

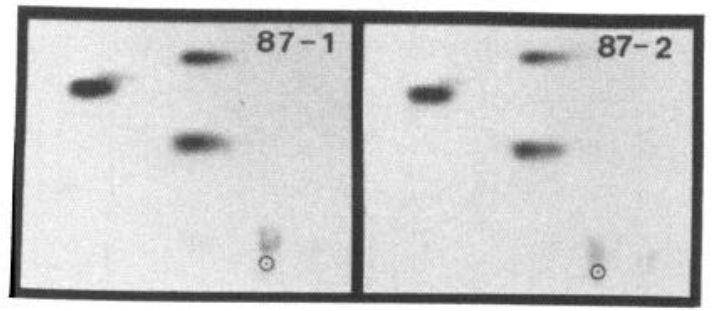

B

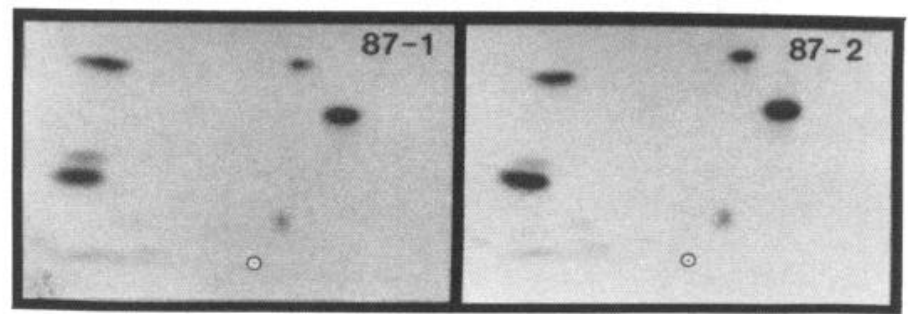

Figure 7. Phosphopeptide fingerprints of $87-\mathrm{kDa}$ and $48-\mathrm{kDa}$ proteins. Phosphoproteins were excised from two-dimensional gels of total neuronal protein $(A, B$, and $D)$ or from one-dimensional gels of immunoprecipitates (C). A shows tryptic fingerprints for 87 $\mathrm{kDa}$ isoelectric variants 1 and 2 . $B$ shows thermolytic fingerprints for $87-\mathrm{kDa}$ isoelectric variants 1 and 2. $C$ shows thermolytic fingerprints of immunoprecipitated $87-\mathrm{kDa}$ protein (variants 1 plus 2) from control and glutamate $(100 \mu \mathrm{M}$ for $30 \mathrm{sec}$ )-treated pyramidal neurons. $D$ shows thermolytic fingerprints of 48 $\mathrm{kDa}$ isoelectric variants 1,2 , and 3 . In all panels, electrophoresis was conducted at pH 3.5 horizontal direction (anode at left, origin indicated by $\odot$ ) followed by chromatography in the vertical dimension.

\section{C}
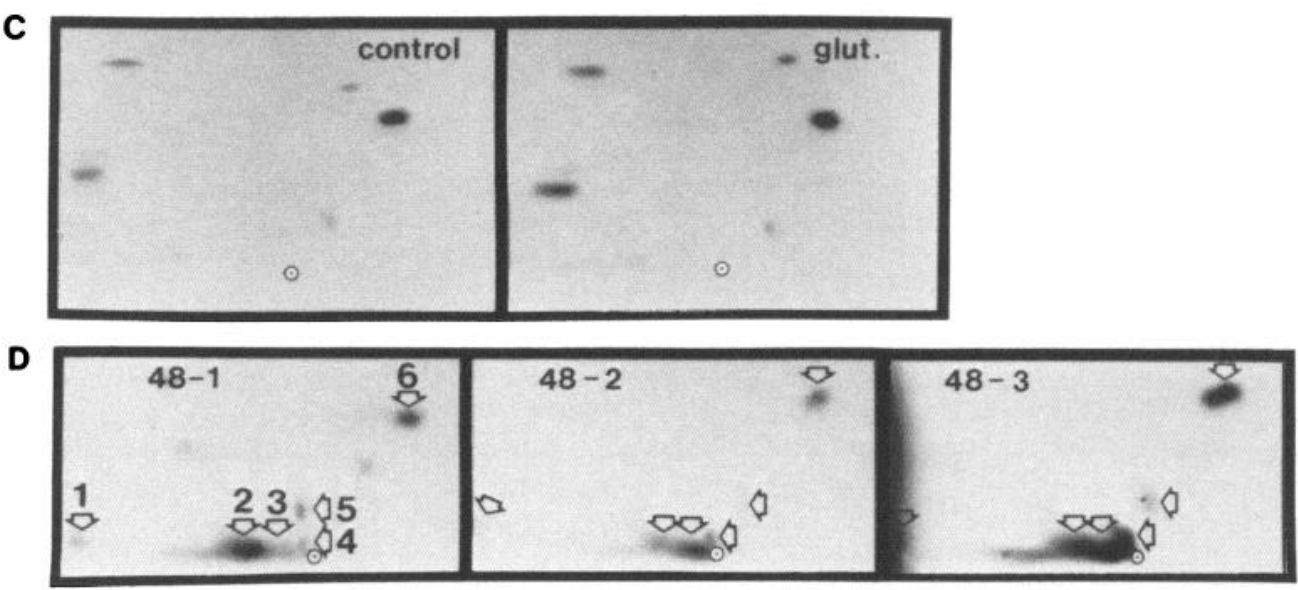

ramidal neurons. The protein was found to be widely distributed and present in neuronal cell bodies, dendrites, and growth cones (Fig. 9).

The 48-kDa protein displayed a number of characteristics in common with GAP-43, including acidic isoelectric point, apparent molecular weight, multiple isoelectric variants, and phosphorylation in neurons but not astrocytes. A polyclonal antibody raised against GAP-43 recognized a single band in gels of total pyramidal neuron protein (Fig. $8 a$ ) and was able to immunoprecipitate a phosphoprotein from neurons incubated in the presence and absence of glutamate (Fig. $8 b$, lanes 3,4 ). However, only a small increase $(<15 \%)$ in the phosphorylation of GAP43 was observed compared to the $130 \%$ increase in $48-\mathrm{kDa}$ protein phosphorylation observed $30 \mathrm{sec}$ after glutamate stimulation. A monoclonal antibody recognizing GAP-43 was used to immunolabel blots of ${ }^{32} \mathrm{P}$-labeled proteins from pyramidal neurons incubated in the presence and absence of glutamate (Fig. 10). Following immunolabeling, the nitrocellulose sheet was autoradiographed. We found that this antibody (and other anti-GAP-43 antibodies) did not recognize the $48-\mathrm{kDa}$ phosphoprotein but a different phosphoprotein with a slightly higher molecular weight $(\approx 50 \mathrm{kDa})$ and less acidic isoelectric point. GAP-43 was resolved into three isoelectric variants, two of which were ${ }^{32} \mathrm{P}$ labeled. Glutamate stimulated a relatively small change in ${ }^{32} \mathrm{P}$ incorporation and little change in isoelectric point (Fig. 10; see also Fig. 3, arrowheads). A further distinction between the $48-\mathrm{kDa}$ protein and GAP-43 was found at the de- velopmental level. GAP-43 was expressed in pyramidal neurons after $4 \mathrm{~d}$ in culture. Immunoblot, immunocytochemistry, and two-dimensional gel analyses of ${ }^{32} \mathrm{P}$-labeled proteins failed to detect GAP-43 in pyramidal neurons in culture for less than 4 d. On the other hand, the 48-kDa phosphoprotein and MARCKS could be detected by two-dimensional gel analyses of ${ }^{32} \mathrm{P}$-labeled proteins at $1 \mathrm{~d}$ in culture (data not shown). We are currently evaluating further the possible relationship between GAP-43 and the 48-kDa protein.

The $120-\mathrm{kDa}$ protein has not been examined in as great detail to date. Preliminary studies indicate that it is associated with the particular fraction, is found in neurons but not astrocytes, has an isoelectric point between 4 and 5 , and appears in pyramidal neurons after $10 \mathrm{~d}$ in culture. By immunological criteria, this protein does not appear to be the cytoskeletal protein and PKC substrate $\alpha$-adducin (Palfrey and Waseem, 1988). Further work is needed to characterize this phosphoprotein.

\section{Discussion}

The actions of glutamate in the CNS appear to be mediated, at least in part, by modulation of protein phosphorylation systems. The results presented here demonstrate for the first time that glutamate stimulates a rapid transient elevation of DAG and protein phosphorylation in cultured hippocampal pyramidal neurons. This effect appears to be quite selective, resulting in an increased phosphorylation of primarily three acidic proteins that is maximal at about $30 \mathrm{sec}$ and returns rapidly to near 


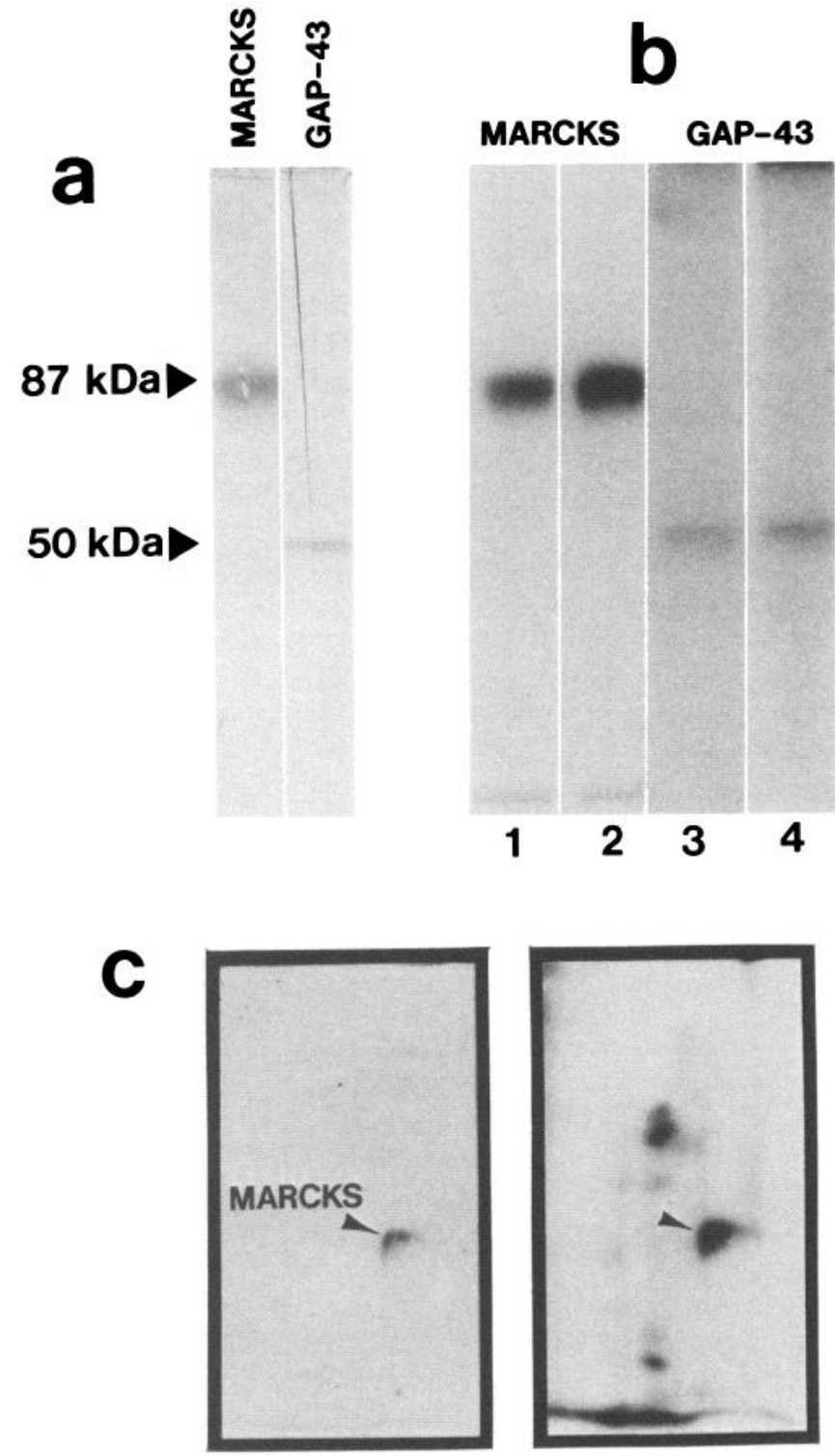

Figure 8. Immunological recognition of MARCKS and GAP-43 in pyramidal neurons. $A$ shows a nitrocellulose transfer of total pyramidal neuron protein separated by SDS-PAGE and reacted with anti-MARCKS or anti-GAP-43 polyclonal rabbit antibodies. $B$ shows an autoradiogram of immunoprecipitates of MARCKS (lanes 1, 2) and GAP-43 (lanes 3, 4) from pyramidal neurons phosphorylated under basal conditions (lanes 1,3$)$ or following glutamate $(100 \mu \mathrm{M}$; lanes 2,4$)$ stimulation for $30 \mathrm{sec}$. Autoradiography of lanes 1 and 2 required exposure for $3 \mathrm{~d}$, while lanes 3 and 4 required $10 \mathrm{~d}$. In $C$, ${ }^{32} \mathrm{P}$-labeled neuronal proteins were separated on two-dimensional gels, then transferred to nitrocellulose. The nitrocellulose sheet was immunolabeled with antiMARCKS antibody (left) and then autoradiographed to reveal ${ }^{32} \mathrm{P}$ incorporation (right). An exact coincidence between anti-MARCKS staining and the 87-kDa phosphoprotein was found.

baseline levels by $2 \mathrm{~min}$. Our results suggest that the effect of glutamate is mediated by PKC because the glutamate-stimulated rise in DAG is temporally correlated with the change in phosphorylation state, and phorbol ester addition also increased the phosphorylation of these same proteins. In addition, the increased phosphorylation of MARCKS following glutamate stimulation strongly suggests PKC activation because this protein has been shown to be exclusively phosphorylated in vitro

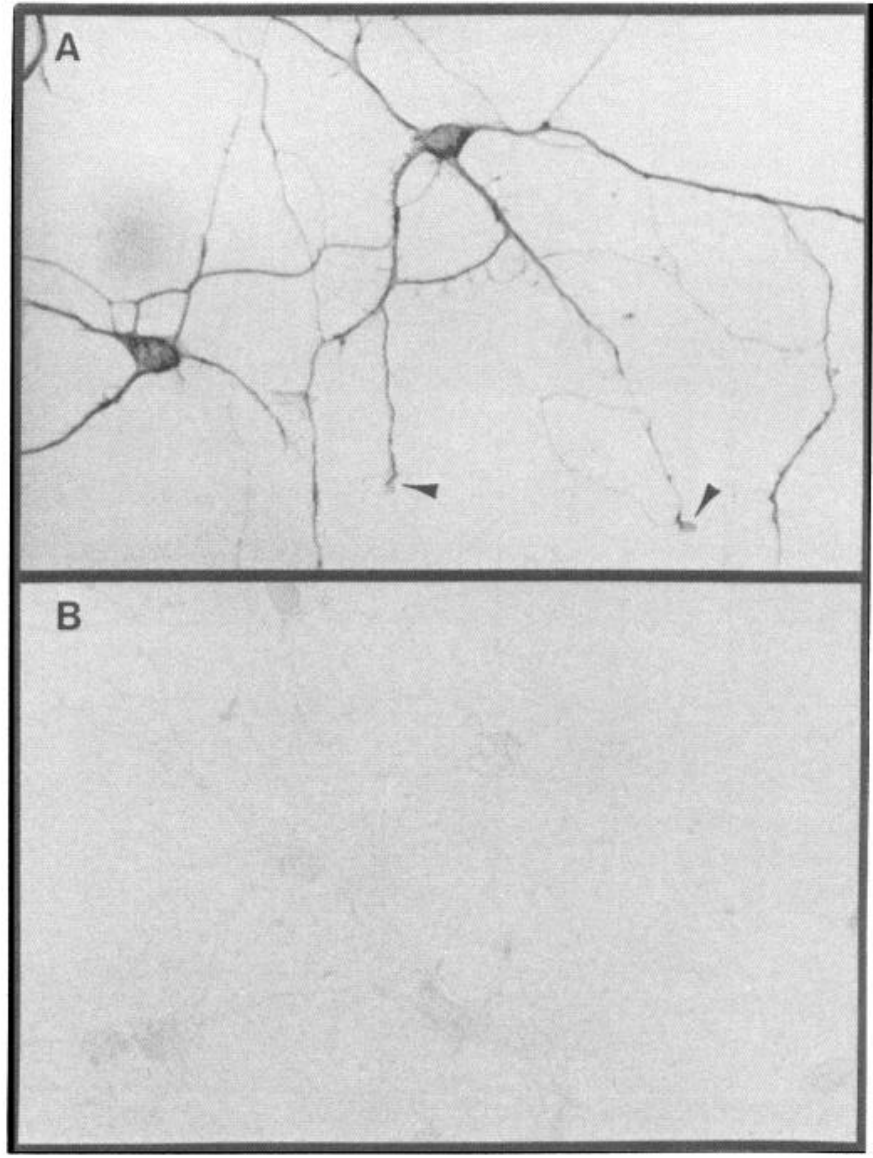

Figure 9. Immunolocalization of MARCKS in cultured pyramidal neurons. $A$, Pyramidal neurons, in culture for 10-14 d, were reacted with anti-MARCKS antibody. Visualization of immunological reaction was by biotinylated secondary antibody followed by an avidin-biotinylated HRP complex with diaminobenzidine tetrahydrochloride as substrate. Arrowheads indicate growth cones. $B$ shows a control in which normal rabbit serum was used as the primary antibody.

and in vivo by PKC (Albert et al., 1986; Blackshear et al., 1986; Rodriguez-Pena and Rozengurt, 1986; Wang et al., 1989). The selectivity of the glutamate effect, as compared to the more general increase in protein phosphorylation seen with either elevated $\left[\mathrm{K}^{+}\right]$or TPA treatment of these cultures, could be due to the localized nature of the glutamate response, direct association of glutamate receptors with the second-messenger system, or possibly the selective activation of a particular isozyme of PKC (PKC isozymes are known to be heterogeneously distributed in the nervous system; for reviews, see Nishizuka, 1988; Huang, 1989). TPA would be expected to massively activate species of PKC; thus, it is not surprising that many proteins become phosphorylated after this treatment. Of the three major substrates, the $87-\mathrm{kDa}$ protein was positively identified as MARCKS, but the other two stimulated phosphoproteins of $120 \mathrm{kDa}$ and $48 \mathrm{kDa}$ appear to be novel PKC substrates not previously described in hippocampal neurons.

\section{Signal transduction via glutamate receptors}

The nature of the glutamate receptor(s) responsible for the events described here is unclear. Glutamate activates several different receptor subtypes leading to complex responses. The activation of phospholipases and the release of DAG and inositol phos- 
A

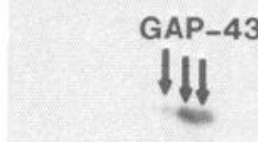

C

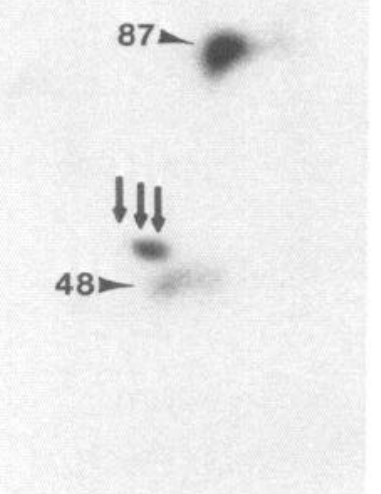

B

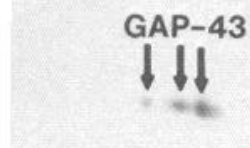

D
Figure 10. Colocalization of GAP-43 immunoreactivity and ${ }^{32} \mathrm{P}$ labeling on two-dimensional gels of pyramidal neurons phosphorylated in the presence and absence of glutamate. GAP-43 immunoreactivity was examined on nitrocellulose transfers of two-dimensional gels of pyramidal neurons preincubated with ${ }^{32} \mathrm{P}_{\mathrm{i}}$ and left untreated $(A)$ or stimulated with glutamate $(B)$. The sheets of nitrocellulose were then placed under film to produce the autoradiograms directly below each panel $(C$ and $D$ ). The arrows indicate isoelectric variants recognized by GAP-43 monoclonal antibody and their location on the corresponding autoradiograms.

phates could occur through at least two separate mechanisms. One possibility is by indirect $\mathrm{Ca}^{2+}$ activation of an enzyme such as phospholipase C (Hynie et al., 1989; Milani et al., 1990); a second possibility is direct receptor-phospholipase coupling, perhaps mediated by a G-protein (Nicoletti et al., 1988). Because NMDA, kainate, and AMPA receptor subtypes are themselves ion channels, their effects on inositol phospholipid hydrolysis might be mediated by an increase in intracellular $\left[\mathrm{Ca}^{2+}\right]$, which has been shown to activate directly phospholipase $\mathrm{C}$ in adrenal chromaffin cells (Eberhard and Holz, 1987). The fact that we were able to stimulate an increase in DAG generation and protein phosphorylation in the absence of a rise in intracellular
$\left[\mathrm{Ca}^{2+}\right]$ suggests that glutamate receptor binding is directly linked to DAG production when cells are stimulated in $50 \mathrm{nM} \mathrm{Ca}^{2+}$ and that elevations in DAG alone are sufficient to activate PKC at basal intracellular $\mathrm{Ca}^{2+}$ levels in these cells. However, decreasing extracellular $\mathrm{Ca}^{2+}$ to $50 \mathrm{~nm}$ did cause some reduction in glutamate-stimulated DAG generation and phosphorylation. This may represent the additive nature of $\mathrm{Ca}^{2+}$-activated and receptor-coupled activation of phospholipases.

Many studies have shown that phospholipases may be directly activated by a receptor-coupled event. Previous indications are that more than one subtype of glutamate receptor is coupled to phosphatidylinositol turnover in this way. For instance, in cultured cerebellar granule cells, an NMDA-sensitive glutamate receptor was reported to be directly coupled to phospholipase C (Wroblewski et al., 1987; Costa et al., 1988). A second type of metabotropic glutamate receptor that has been proposed is selectively activated by ibotenate (for review, see Sladeczek et al., 1988). Third, a CNQX-insensitive quisqualate receptor (designated $\mathrm{Q}_{\mathrm{p}}$ or trans-ACPD) has been shown in cultured neurons to increase the generation of inositol phosphates (Nicoletti et al., 1988; Manzoni et al., 1990; Patel et al., 1990), and an analogous receptor has been shown in cultured mouse hippocampal neurons to increase intracellular $\left[\mathrm{Ca}^{2+}\right]$ in the absence of extracellular $\mathrm{Ca}^{2+}$ (Murphy and Miller, 1988). In the present study, glutamate-stimulated phosphorylation did not occur in the presence of CNQX. Therefore, the $\mathrm{Q}_{\mathrm{p}}$ receptor examined by Murphy and Miller (1988) was probably not involved. In fact, we could not detect a change in $\mathrm{Ca}^{2+}$, DAG, or phosphorylation levels following quisqualate $(100 \mu \mathrm{M})$ addition to cultured pyramidal neurons (data not shown), possibly because only a small portion of these cells may contain quisqualate receptors (Glaum et al., 1990). The most likely candidate for receptor-coupled release of DAG in the absence of $\mathrm{Ca}^{2+}$ influx is the ibotenate-activated subtype, because recent results demonstrate that ibotenate stimulates the generation of inositol phosphates in cultured pyramidal neurons in $50 \mathrm{~nm}\left[\mathrm{Ca}^{2+}\right]$ (W. K. Scholz and H. C. Palfrey, unpublished observations). We are currently in the process of determining the glutamate receptor subtype(s) responsible for the transient rise in second-messenger levels and protein phosphorylation described here.

\section{Glutamate-stimulated protein phosphorylation}

Of the three phosphoproteins described in this study, the 87$\mathrm{kDa}$ species was positively identified as MARCKS by a number of criteria, including immunological cross-reactivity. MARCKS is a well-studied protein that appears to be solely phosphorylated by PKC (Albert et al., 1986; Blackshear et al., 1986; RodriguezPena and Rozengurt, 1986; Wang et al., 1989), but is not nervous system specific (Albert et al., 1986). The amino acid sequence of MARCKS has been deduced from its cDNA sequence (Stumpo et al., 1989). The deduced $M$, of 31,000 differs from the apparent $M$, of the protein by SDS-PAGE, probably because of the elongated nature of the molecule. Though its function is not understood, MARCKS has several interesting features that suggest it plays an important regulatory role in cell function. These include its ability to bind calmodulin and its reversible association with membranes (Stumpo et al., 1989). Depolarization of synaptosomes results in an increase in MARCKS phosphorylation and translocation of the protein from membrane to cytosol (Wang et al., 1989) as well as a reduction in the ability of the protein to bind calmodulin (Stumpo et al., 1989).

As shown here, a reversible acidic isoelectric shift of MARCKS 
occurs with glutamate-stimulated phosphorylation. A similar acidic shift has been reported in the presumptive MARCKS homologue in lymphocytes following phorbol ester treatment (Hornbeck et al., 1989) and in fibroblasts following TPA or lysophosphatidate treatment (van Corven et al., 1989). In the present studies, tryptic and thermolytic digests of MARCKS produced three and four phosphorylated peptides, respectively, suggesting that four or fewer sites are phosphorylated in situ. This is in agreement with the number of sites predicted by the deduced amino acid sequence of MARCKS (Stumpo et al., 1989). Contrary to expectation, phosphopeptide analyses of the least acidic (basal) and acidic (stimulated) variants failed to reveal an additional phosphorylation site. One explanation of this sccmingly paradoxical rcsult is that under basal conditions the least acidic isoelectric form represents a heterogeneous population of phosphoforms containing the same number of phosphates (e.g., one) but at different sites. The glutamate-stimulated acidic shift could then represent increased incorporation of phosphate at unoccupied sites such that all phosphoforms contain an additional phosphate (e.g., two).

An alternative explanation for the glutamate-stimulated isoelectric shift of MARCKS could be that a transient covalent modification in addition to phosphorylation is involved. Aderem et al. (1988) have shown that lipopolysaccharides stimulated the myristoylation of MARCKS in macrophages. Most of the myristoylated protein was found to be membrane associated. When macrophages were pretreated with lipopolysaccharides, phosphorylation stimulated by phorbol esters was enhanced, perhaps due to myristoylation-induced membrane association of MARCKS. Phorbol ester-stimulated phosphorylation was concurrent with demyristoylation and the release of MARCKS into the cytosol. Though myristoylation does not introduce a negative charge, it might cause a conformational change that exposes more acidic residues, thus causing an acidic isoelectric shift. Further studies to investigate whether myristoylation plays a role in glutamate signal transduction are necessary.

At first we suspected that the $48-\mathrm{kDa}$ glutamate-stimulated phosphoprotein was GAP-43. This protein is a well-defined PKC substrate that is neuron specific and has been implicated in axonal growth processes in neuronal growth cones and synaptic plasticity in the adult brain (for review see Skene, 1989). GAP-43 is an acidic protein with an apparent molecular weight of $43-57 \mathrm{kDa}$ by SDS-PAGE, within the range of the $48-\mathrm{kDa}$ phosphoprotein observed here. However, our attempts to immunoprecipitate or immunolabel the 48-kDa phosphoprotein with a variety of anti-GAP-43 antibodies were unsuccessful; instead, a different, slightly less acidic phosphoprotein of approximately $50 \mathrm{kDa}$ reacted with these antibodies. The phosphorylation state of authentic GAP-43 was found to be only marginally affected by glutamate in the present study. In contrast, the $48-\mathrm{kDa}$ protein showed a marked increase in total ${ }^{32} \mathrm{P}$ incorporation and a significant acidic isoelectric point shift following glutamate addition to pyramidal neurons. Peptide mapping showed that the acidic shift was accompanied by an increase in the total number of thermolytic phosphopeptides. The nature of the $48-\mathrm{kDa}$ phosphoprotein as well as the other unidentified glutamate-stimulated phosphoprotein of $120 \mathrm{kDa}$ is currently under investigation.

In pyramidal neuron cultures, phosphorylation of MARCKS and the $48-\mathrm{kDa}$ protein is most prominent from 1 to $5 \mathrm{~d}$ in culture at a time when growth cones are most evident. In contrast, GAP- 43 is expressed at $4 \mathrm{~d}$, decreasing slightly by 2 weeks in culture. Preliminary results indicate that glutamate $(30 \mu \mathrm{M})$ addition to cultures 2-3-weeks old causes a significant increase in the levels of both the 48-kDa protein and MARCKS, when assayed by phosphorylation $2-4 \mathrm{~d}$ later. Moreover, growth cones (rare in cultures of this age) become quite evident by $2 \mathrm{~d}$ following treatment. Thus, the appearance of phosphorylated MARCKS and the 48-kDa protein correlates with the appearance of glutamate-stimulated growth. It will consequently be of interest to investigate further the role of these molecules in both the trophic and the neurotransmitter responses to glutamate in this cell population.

\section{References}

Aderem AA, Albert KA, Keum MM, Wang JK-T, Greengard P, Cohn ZA (1988) Stimulus-dependent myristoylation of a major substrate for protein kinase C. Nature 332:362-364.

Albert KA, Walaas SI, Wang JK-T, Greengard P (1986) Widespread occurrence of " $87-\mathrm{kDa}$ " a major specific substrate for protein kinase C. Proc Natl Acad Sci USA 83:2822-2826.

Andreason TJ, Luetje CW, Heidman W, Storm DR (1983) Purification of a novel calmodulin binding protein from bovine cerebral cortex. Biochemistry 22:4615-4618.

Banker GA, Cowan WM (1977) Rat hippocampal neurons in dispersed cell culture. Brain Res 126:397-425.

Bartlett WP, Banker GA (1984) An electron microscopic study of the development of axons and dendrites by hippocampal neurons on culture. I. Cells which develop without intercellular contacts. Neurosci 4:1944-1953.

Berridge MJ (1988) Inositol lipids and calcium signalling. Proc R Soc Lond [Biol] 234:359-378.

Blackshear PJ, Wen L, Glynn BP, Witters LA (1986) Protein kinase C-stimulated phosphorylation in vitro of a $M, 80,000$ protein phosphorylated in response to phorbol esters and growth factors in intact fibroblasts. Distinction from protein kinase $\mathrm{C}$ and prominence in brain. J Biol Chem 261:1459-1469.

Blake JF, Brown MW, Collingridge GL (1988) CNQX blocks acidic amino acid induced depolarizations and synaptic components mediated by non-NMDA receptors in rat hippocampal slices. Neurosci Lett 89:182-186.

Booher J, Sensenbrenner M (1972) Growth and cultivation of dissociated neurons and glial cells from embryonic chick, rat and human brain in flask cultures. Neurobiology 2:97-105.

Bottenstein JE, Sato GH (1979) Growth of a rat neuroblastoma cell line in serum-free supplemented medium. Proc Natl Acad Sci USA 76:514-519.

Cimler BM, Andreasen TJ, Andreasen KI, Storm DR (1985) P-57 is a neural specific calmodulin-binding protein. J Biol Chem 260:1078410788 .

Costa E, Fadda E, Kozikowski AP, Nicoletti F, Wroblewski JT (1988) Classification and allosteric modulation of excitatory amino acid signal transduction in brain slices and primary cultures of cerebellar neurons. In: Neurobiology of amino acids, peptides and trophic factors (Ferrendelli JA, Collins RC, Johnson EM, eds), pp 35-50. Boston: Kluwer Academic.

Davies JD, Francis AA, Jones AW, Watkins JC (1981) 2-Amino-5phosphonovalerate (2-APV), a potent and selective antagonist of amino acid induced and synaptic excitation. Neurosci Lett 21:77-81.

Eberhard DA, Holz RW (1987) Cholinergic stimulation of inositol phosphate formation in bovine adrenal chromaffin cells: distinct nicotinic and muscarinic mechanisms. J Neurochem 49:1634-1643.

Glaum SR, Scholz WK, Miller RJ (1990) Acute- and long-term glutamate-mediated regulation of $\left[\mathrm{Ca}^{2+}\right]_{i}$ in rat hippocampal pyramidal neurons in vitro. J Pharmacol Exp Ther 253:1293-1302.

Grynkiewicz G, Poenie M, Tsien RY (1985) A new generation of $\mathrm{Ca}^{2+}$ indicators with greatly improved fluorescence properties. J Biol Chem 260:3440-3450.

Halpain S, Greengard P (1990) Activation of NMDA receptor induces rapid dephosphorylation of the cytoskeletal protein MAP2. Neuron 5:237-246.

Hemmings HC, Nairn AC, McGuinness TL, Huganir RL, Greengard $P$ (1989) Role of protein phosphorylation in neuronal signal transduction. FASEB J 3:1583-1592. 
Hornbeck P, Nakabayashi H, Fowlkes BJ, Paul WE, Kligman D (1989) $A$ major myristoylated substrate of protein kinase $C$ and protein kinase $\mathrm{C}$ itself are differentially regulated during murine $\mathrm{B}$ - and T-lymphocyte development and activation. Mol Cell Biol 9:37273735.

Huang K-P (1989) The mechanism of protein kinase $C$ activation. Trends Neurosci 12:425-432.

Hynie S, Wroblewski JT, Costa E (1989) Profile of phosphatidylinositol metabolism by carbachol and glutamate in primary cultures of rat cerebellar neurons. Neuropharmacology 28:1309-1315.

Katz F, Ellis L, Pfenninger KH (1985) Nerve growth cones isolated from fetal rat brain. III. Calcium-dependent protein phosphorylation. J Neurosci 5:1402-1412.

Manzoni OJJ, Finiels-Marlier F, Sassetti I, Bockaert J, LePeuch C, Sladeczek $F$ (1990) The glutamate receptor of $Q_{p}$ type activates protein kinase $C$ and is regulated by protein kinase $C$. Neurosci Lett 109:146-151.

Milani D, Facci I, Buso M, Toffano G, Leon A, Skaper D (1990) Excitatory amino acid receptor agonists stimulate membrane inositol phospholipid hydrolysis and increase cytoplasmic free $\mathrm{Ca}^{2+}$ in primary cultures of retinal neurons. Cell Signalling 2:359-368.

Monaghan DT, Bridges RJ, Cotman CW (1989) The excitatory amino acid receptors: their classes, pharmacology and distinct properties in the function of the central nervous system. Annu Rev Pharmacol Toxicol 29:365-402.

Murphy SN, Miller RJ (1988) A glutamate receptor regulates $\mathrm{Ca}^{2+}$ mobilization in hippocampal neurons. Proc Natl Acad Sci USA 85: 8737-8741.

Nelson RB, Routtenberg A (1985) Characterization of protein F1 (47 $\mathrm{kDa}, 4.5 \mathrm{pI}$ ): a kinase $\mathrm{C}$ substrate directly related to neural plasticity. Exp Neurol 89:213-224.

Nicoletti F, Wroblewski JT, Novelli A, Alho H, Guidotti A, Costa E (1986) The activation of inositol phospholipid metabolism as a signal-transducing system for excitatory amino acids in primary cultures of cerebellar granule cells. J Neurosci 6:1905-1911.

Nicoletti F, Wroblewski JT, Fadda E, Costa E (1988) Pertussis toxin inhibits signal transduction at a specific metabolotropic glutamate receptor in primary cultures of granule cells. Neuropharmacology 27: $551-556$

Nishizuka $Y$ (1986) Studies and perspectives of protein kinase C. Science 233:305-312.

Nishizuka Y (1988) The molecular heterogeneity of protein kinase C and its implications for cellular regulation. Nature 334:661-665.

O'Farrell PH (1975) High resolution two-dimensional electrophoresis of proteins. J Biol Chem 250:4007-4021.

Palfrey HC, Mobley P (1987) Second messengers and protein phosphorylation in the nervous system. In: Neurochemistry: a practical approach (Turner AJ, Bachelard HS, eds), pp 161-192. Oxford: IRL.

Palfrey HC, Waseem A (1988) Protein kinase C and its associated substrates in the human erythrocyte. Symp Soc Gen Physiol 41:357369.

Patel J, Moore WC, Thompson C, Keith RA, Salama AI (1990) Characterization of the quisqualate receptor linked to phosphoinositide hydrolysis in neocortical cultures. J Neurochem 54:1461-1466.

Pearce B, Albrecht J, Morrow C, Murphy S (1986) Astrocyte glutamate receptor activation promotes inositol phospholipid turnover and calcium flux. Neurosci Lett 72:335-340.

Preiss J, Loomis CR, Bishop WR, Stien R, Niedel JE, Bell RM (1986) Quantiative measurement of $s n-1,2$-diacylglycerols present in platelets, hepatocytes, and ras-and sis-transformed normal rat kidney cells. J Biol Chem 261:8597-8600.

Recasens M, Sassetti I, Nourgat A, Sladeczek F, Bockaert J (1987) Characterization of subtypes of excitatory amino acid receptors involved in the stimulation of inositol phosphate synthesis in rat brain synaptosomes. Eur J Pharmacol 141:87-93.

Rodriguez-Pena A, Rozengurt E (1986) Phosphorylation of an acidic
$M_{r} 80,000$ cellular protein in a cell-free system and intact Swiss 3T3 cells: a specific marker of protein kinase $C$ activity. EMBO J 5:7783.

Ross CA, Meldolesi J, Milner TA, Satoh T, Supattapone S, Snyder SH (1989) Inositol 1,4,5-trisphosphate receptor localized to endoplasmic reticulum in cerebellar Purkinje neurons. Nature 339:468-470.

Scholz KP, Miller RJ (1991) Analysis of adenosine actions on calcium currents and synaptic transmission in cultured rat hippocampal pyramidal neurons. J Physiol (Lond) 435:373-393.

Skene, JHP (1989) Axonal growth-associated proteins. Annu Rev Neurosci 12:127-156.

Skene JHP, Willard M (1981a) Changes in axonally transported proteins during axon regeneration in toad retinal ganglion cells. J Cell Biol 89:86-95.

Skene JHP, Willard M (1981b) Axonally transported proteins associated with axon growth in rabbit central and peripheral nervous systems. J Cell Biol 89:96-103.

Sladeczek F, Pin J-P, Recasens M, Bockaert J, Weiss S (1985) Glutamate stimulates inositol phosphate formation in striatal neurones. Nature 317:717-719.

Sladeczek F, Recasens M, Bockaert J (1988) A new mechanism for glutamate receptor action: phosphoinositide hydrolysis. Trends Neurosci 11:545-549.

Stumpo DJ, Graff JM, Albert KA, Greengard P, Blackshear PJ (1989) Molecular cloning, characterization, and expression of a CDNA encoding the "80- to 87-kDa" myristoylated alanine-rich $\mathrm{C}$ kinase substrate: a major cellular substrate for protein kinase C. Proc Natl Acad Sci USA 86:4012-4016.

Thayer SA, Sturek M, Miller RJ (1988) Measurements of neuronal $\mathrm{Ca}^{2+}$ transients using simultaneous microfluorimetry and electrophysiology. Pfluegers Arch 412:216-223.

Towbin H, Staehelin T, Gordin J (1979) Electrophoretic transfer of proteins from polyacrylamide gels to nitrocellulose sheets: procedure and some applications. Proc Natl Acad Sci USA 76:4350-4354.

van Corven EJ, Groenink A, Jalink K, Eichholtz T, Moolenaar WH (1989) Lysophosphatidate-induced cell proliferation: identification and disscetion of signaling pathways mediated by $G$ protcins. Cell 59:45-54.

Wang JK-T, Walaas SI, Sihra TS, Aderem A, Greengard P (1989) Phosphorylation and associated translocation of the $87-\mathrm{kDa}$ protein, a major protein kinase $\mathrm{C}$ substrate, in isolated nerve terminals. Proc Natl Acad Sci USA 86:2253-2256.

Watkins JC, Evans RH (1981) Excitatory amino acid receptors. Annu Rev Pharmacol Toxicol 21:165-204.

Waymire JC, Johnston JP, Lickteig KH, Lloyd A, Vigny A, Craviso GL (1988) Phosphorylation of bovine adrenal chromaffin cell tyrosine hydroxylase. Temporal correlation of acetylcholine's effect on site phosphorylation, enzyme activation, and catecholamine synthesis. $J$ Biol Chem 263:12439-12447.

Westbrook GL, Jahr CE (1989) Glutamate receptors in excitatory neurotransmission. Semin Neurosci 1:103-114.

Wright TM, Rangan LA, Shin HS, Raben DM (1988) Kinetic analysis of 1,2-diacylglycerol mass levels in cultured fibroblasts. Comparison of stimulation by $\alpha$-thrombin and epidermal growth factor. J Biol Chem 263:9374-9380.

Wroblewski JT, Nicoletti F, Fadda E, Costa E (1987) Phencyclidine is a negative allosteric modulator of signal transduction at two subclasses of excitatory amino acid receptors. Proc Natl Acad Sci USA 84:5068-5072.

Wu WC-S, Walaas SI, Nairn AC, Greengard P (1982) Calcium/phospholipid regulated phosphorylation of a $M_{r}$ " $87 \mathrm{k}$ " substrate protein in brain synaptosomes. Proc Natl Acad Sci USA 79:5249-5253.

Zwiers, H, Schotman P, Gispen WH (1980) Purification and some characteristics of an ACTH-sensitive protein kinase and its substrate protein in rat brain membranes. J Neurochem 34:1689-1699. 